\title{
Analysis of Implementation of Robotic Process Automation : A Case Study in PT X
}

\author{
Ricky Arnaz ${ }^{1, *}$ Muslim Efendi Harahap ${ }^{1}$ \\ ${ }^{1}$ Faculty of Economics and Business Universitas Indonesia Jakarta, Indonesia \\ ${ }^{*}$ Corresponding author. Email: rickyarnaz7@gmail.com
}

\begin{abstract}
PT X as one of the largest manufacturing companies in Indonesia, has a large workforce and assets, complex business processes and has an important portion in the market share in the industry. PT X has decided to implement Robotic Process Automation (RPA) initiative which is expected to make operational processes leaner and more efficient. But after it was implemented, was it true that RPA had a positive effect on PT X? This paper discusses the implementation of RPA at PT X, the effects and cost-benefit analysis of RPA implementation in the company. The analysis was conducted by focusing on the implementation of the RPA in the vendor payment process at PT X by using cost-benefit analysis based on qualitative and quantitative approaches. A qualitative approach was carried out using the interview method with key stakeholders from the implementation of the RPA coming from internal and external PT X. The quantitative approach is carried out using business process analysis and financial accounting methods. This study produces conclusions on the positive effects of the implementation of the RPA that can be seen from decrease of lead time vendor payment process up to $97.8 \%$ and decrease of Employee cost up to 55\%.
\end{abstract}

Keywords - Robotic Process Automation, Cost-Benefit Analysis, Qualitative and Quantitative Approaches

\section{INTRODUCTION}

Since 2011, the business and industrial world has entered the Industrial Revolution 4.0 marked by increased connectivity, interaction and boundaries between people, machines and other resources that are increasingly converging through information and communication technology [1]. One of the five main factors in the industrial revolution 4.0 is robotics technology or another term that we often hear is Robotic Process Automation (RPA). RPA is the concept of using robots to replace human work. The robot referred to in this context is not a physical robot sitting in front of a computer and working like humans, but software that is programmed to work like humans [2].

As a large company engaged in the automotive industry, PT X has a big portion in market share, a large workforce and assets, including complex business processes. PT X's large and complex scale has the potential consequence of high operational costs so that it can erode the company's profit in the future if it is not managed properly. PT X ideally has a lean and efficient operational process. One of the RPA strategy initiatives, in addition to reducing labor costs, is expected to reduce the potential for human error and speed up the process or reduce lead time of operations. The implementation of this RPA will provide optimal benefits if it is applied to a standard, repeatable process and involves a large workforce. Some preliminary initiatives such as digitizing document for shipping and billing are good initial steps and can support the acceleration of the RPA initiative. Based on these conditions, PT X decided to apply the RPA in the process of payment of trade payables or $\mathrm{A} / \mathrm{P}$ (Account Payable) to the vendor because it was considered to be more ready and provide positive effects if the RPA was implemented. In its application, the RPA requires a large amount of investment with an initial estimate of more than IDR 3 billion and will have a negative impact on PT X's internal and external processes if the implementation of this RPA is not as expected.

The aim of this study is to analyze whether the implementation of the RPA will give positive effects to the PT $\mathrm{X}$ or not, using tangible and intangible approaches. 


\section{MATERIALS AND METHODS}

\subsection{Literature Study}

The term Robotic Process Automation (RPA) was first used in 2012 by Blue Prism's Marketing Director, Patrick Geary. But the European Patent Office (EPO) recognizes Cyrille Bataller and Adrien Jacquot as the inventors of the RPA. Cyrille Bataller and and Adrien Jacquot define RPA as a technology that makes it possible to automate the implementation of repetitive and intensive activities manually [3]. Gartner has another definition for RPA that RPA is a productivity tool (sold as licensed software) that allows users to configure one or more scripts (the other term is bot) to activate certain key presses in an automatic way [3]. RPA is an emerging technology that is based on the use of virtual robots to mimic human interactions in various systems [4]. RPA robots can be programmed to do repetitive and rule-based tasks in place of humans in a faster and more accurate way [4]. RPA can operate on top of existing systems without disrupting one system because it only mimics human activities such as digital versions of human employees [4]. One bot can be assigned several tasks or several bots can be assigned to do one task depending on the volume of the task [4].

One of the cost benefit analysis methods for implementing RPA is Cost benefit analysis based on Financial Accounting. This analysis method uses a number of formulas and standard measures used in financial accounting management. An example is using the formula ROI, IRR, NPV, etc. as a tool to assess whether an investment is considered feasible, reasonable, and worth for a company - moreover from the aspect of financial resources [5]. One of the biggest challenges in assessing the feasibility of an RPA investment is assessing or estimating what benefits the company will get later. This is said to be a challenge because the benefits provided by information technology can be intangible or difficult to quantify into financial units and do not directly affect the profitability of the company. David Silk in 1990 offered steps to assist management in measuring the benefits of the intangible [6]. Hence RPA has been proven as one of the reasonably priced and practical solutions to eliminate the need for human labors in repetitive structured task [4]. All definitions emphasize the main purpose of RPA: automation of repetitive tasks using computers or robots. After tasks are automated, cost reductions, problems with management and miscommunication are eliminated, time for task implementation is reduced, productivity and accuracy increase, and human errors are eliminated or mitigated [3]. Studies show that RPA implementation reduces FTE (Full Time Equivalent) costs by 50 percent, while Back Office customer call failures also decrease by 50 percent [3].

\subsection{Research Methodology}

In analyzing the cost benefit analysis of implementing RPA, this paper uses the tangible and intangible benefit analysis approaches. Tangible analysis uses an analysis based on Financial Accounting that uses several indicators such as Employee Cost Analysis, Cash Flow Analysis, Net Present Value (NPV) [7], Pay Back Periods (PBP) [8] and Internal Rate of Return (IRR) [9]. While intangible analysis uses a structured interview method [10] for key stakeholders and uses an impact analysis method on several indicators that can be measured such as process $\&$ time analysis [11].

Tangible indicators such as Employee Cost and Cash Flow analysis will be compared in the period before and after the implementation of the RPA. This employee cost component consists of salary \& wages and bonus. Whereas cash flow analysis is more directed to the accuracy of cash flow for a certain period. NPV analysis applies the time value of money to the future cash inflows and cash outflows so management can evaluate a project's benefits and costs at one point in time. The PBP analysis of an investment can be used to see the length of time to recover the initial investment amount. The IRR is a measure of an investment's rate of return. The internal term refers to the fact that the calculation excludes external factors, such as the risk-free rate, inflation, the cost of capital, or various financial risks. It is also called the discounted cash flow rate of return.

Analysis of intangible aspects through structured interviews is emphasized on the feedback from key stakeholders from the adoption of RPA such as Directors, General Managers, Treasury Staff and Suppliers. While the impact analysis will analyze any process changes that occur after the implementation of the RPA along with the measurement of lead time for work processes in the Treasury.

\section{RESULTS}

Based on the analysis of all financial and nonfinancial indicators, application of the RPA has positive effects on business processes and financial aspects and in line with the results of interviews of all related parties. The positive effects generated by the application of the RPA can be seen from all analyzes conducted, namely:

\section{a. Analysis of Interview Results}

The results showed that all respondents stated that the implementation of the RPA at PT X had a positive impact on PT X and its partners (suppliers) such as the duration of business processes that were more lean in process and lead time. 


\section{b. Business Process \& Lead Time Analysis}

The results showed that the business processes in the $\mathrm{A} / \mathrm{P}$ payment process series became leaner than before consisting of 9 main activities to only 5 main activities. In the case of lead time, now the process becomes much shorter where the resulting efficiency level reaches $97.8 \%$, while before was 60.63 hours to be 1.32 hours per day.

\section{c. Employee Cost Analysis}

The results showed the number of employees in the Treasury Division of PT X decreased by 6 people from 11 people before RPA implementation. And there was no need to increase the number of employees due to the increase in $\mathrm{A} / \mathrm{P}$ payment transactions that occurred so that the employee cost that was successfully reduced reached $55 \%$ or IDR 525,000,000 based on current conditions or $75 \%$ from the estimated employee cost with a scenario where the RPA is not applied.

\section{d. Cash Flow Analysis}

Accuracy of cash flow that was previously 2 weeks becomes 4 weeks, thereby reducing the potential for loss interest income of IDR 2,499,273,863. This is due to a more accurate payment schedule so that PT $X$ can optimize the placement of funds in the Bank and get a greater interest income since the adoption of the RPA.

e. Payback Periods (PBP), Net Present Value (NPV) and Internal Rate of Return (IRR) Analysis

The results of these 3 analyzes show that investment in implementing RPA at PT X provides a better value in the future. This can be seen from the PBP for this RPA investment, which is only 1.74 years, with an NPV value of IDR 5.3 Billion and an IRR of $67.2 \%$ from discount rate $15 \%$ p.a.

\section{DISCUSSION}

However, even though all analyzes conducted on the adoption of this RPA showed positive performance, it is worth noting that although the employee cost of the Treasury Division was reduced, the current related employees were transferred to other Divisions that still needs their expertise. Some feedbacks resulted from interviews with Director to Staff levels that are needed to be further considered are aspects of risk management, policies and changes in habits of human resources. This is also in line with research conducted by CristinaClaudia OSMAN [3] that companies must continue to monitor all of their business processes in order to identify and optimize the implementation of RPA, including employee involvement in implementing RPA.

\section{CONCLUSION}

Based on all financial (tangible) and non-financial (intangible) indicators, the application of the RPA has some positive effects on the operational performance of
PT $\mathrm{X}$ and is in line with the results of interviews of all relevant parties. Financial and non-financial indicators that are used as a basis for research conclusions are:

- The lead time for the process of payment of accounts payable (A/P) to the Vendor is $97.8 \%$ shorter, from 60.63 hours to 1.32 hours per day;

- Employee costs in the Treasury Division decreased by $55 \%$ per year or worth IDR 525,000,000,- ;

- Cash flow accuracy increased from 2 weeks to 4 weeks, thereby increasing the potential interest income by IDR 2,499,273,863 per year; and

- The cost of implementing an RPA of IDR 3.49 Billion invested by a company when analyzed from investment indicators and the future value shows a payback period of only 1.74 years and an NPV value of IDR 5.3 Billion and an IRR of $67.2 \%$.

\section{RECOMMENDATIONS}

- In order to have broader positive impacts, the implementation of the RPA should be continued to the PT X's other functions and its supply chain companies. This will make PT $\mathrm{X}$ industrial ecosystem become leaner, more efficient while providing multiple effects for all stakeholders and the economy.

- PT X should conduct an assessment and evaluation of risks and controls due to changes in business processes as a result of the implementation of RPA at PT X so that potential problems can be mitigated earlier. Some key risks based on 5 risk categories for RPA implementation [12] that need to be considered by PT $\mathrm{X}$ are risks related to:

1. Support from Top Management (Executive);

2. Control over Robot access to data and systems (Technical);

3. Impact on Human Resources (Change Management);

4. Performance Monitoring (Operational); and

5. Design overall control over the adoption of the RPA (Functional).

\section{ACKNOWLEDGMENT}

The author would like to acknowledge the support by Rofikoh Rokhim as President of Master of Management, Faculty of Economics and Business, Universitas Indonesia. The author also would like to acknowledge the support by Finance Director of PT X, Treasury Division Head of PT X and thank all parties for their help and support in form of interview completion and data gathering. 


\section{REFERENCES}

[1] https://manufacturingindonesia.com/makingindonesia-4-0-strategi-ri-masuki-revolusi-industri-ke-4/ on 29 November 2019

[2]

https://www.mii.co.id/en/insight/listing/2018/1

$1 / 19 / 03 / 48 /$ robotic-process-automation) on 29 November 2019

[3] Osman, Cristina-Claudia (2019). Robotic Process Automation: Lessons Learned from Case Studies. Informatica Economică vol. 23, no. 4/2019.

[4] Radke, A.M., Dang, M.T., \& Tan, A. (2020). Using robotic process automation (RPA) to enhance Item master data maintenance process. LogForum 16 (1), 129-140.

[5] Indrajit, Richardus Eko (2016). Analisa CostBenefit Investasi Teknologi Informasi. The Preinexus Publisher.

[6] Silk, D.J. (1990). Managing IS Benefits for the 1990s, Journal of Information for MBA Studnets. Henley The Management College.

[7] https://id.wikipedia.org/wiki/NPV on 11 April 2020

[8] https://en.wikipedia.org/wiki/Payback_period on 11 April 2020

[9] https://id.wikipedia.org/wiki/IRR on 11 April 2020

[10] Herdiansyah, H. (2013). Wawancara, observasi, dan focus group: sebagai instrumen penggalian data kualitatif (1st Ed). Jakarta: Rajagrafindo Persada.

[11] Jacobs, F. Robert, and Richard B. Chase. (2018). Operations and Supply Chain Management. 15th Ed., New York: McGraw-Hill Companies Inc.

[12] https://www.pwc.com/us/en/riskassurance/publications/assets/pwc-robotics-processautomation-a-primer-for-internal-audit-professionalsoctober-2017.pdf on September 2019 